\title{
Using Kahoot! as a Gamified Formative Assessment Tool: A Case Study
}

\author{
Süleyman Nihat SSAD ${ }^{1}$ \\ Inonu University, Faculty of Education \\ Niyazi ÖZER ${ }^{2}$ \\ Inonu University, Faculty of Education
}

\begin{abstract}
Digital assessment tools, or electronic classroom response systems, can be used effectively for formative assessment purposes. They can provide teachers with regular and instant feedback about learners' progress to detect and fix the learners' mistakes and misconceptions sustainably in an entertaining way. This case study intended to report researchers' experiences and evaluations about using a popular gamified digital exam platform (Kahoot!) used for formative purposes in a limited context of prospective teacher education program. Both qualitative and quantitative data were collected from 88 prospective teachers from a variety of programs/departments attending a 25credit two-semester teacher training certificate program in Turkey. Results of the study suggested that participants were highly positive about using the digital exam platform as a gamified formative assessment tool from attitudinal and pedagogical aspects. It was concluded that Kahoot! is quite promising in providing an effective formative assessment platform producing favorable practical, pedagogical, and affective outcomes.
\end{abstract}

\section{Suggested Citation:}

Şad, S. N. \& Özer, N. (2019). Using Kahoot! as a gamified formative assessment tool: A case study, International Journal of Academic Research in Education, 5(1), 43-57. DOI: 10.17985/ijare.645584

Prof. Dr., nihat.sad@inonu.edu.tr

${ }_{2}^{2}$ Assoc. Prof. Dr., niyazi.ozer@inonu.edu.tr 


\section{INTRODUCTION}

While formative assessment collects data during instruction to monitor how well learner progress, summative assessment collects data after instruction to make judgments about grading, certification, and evaluation of progress (Bloom, Hastings, and Madaus, 1971). Formative assessment aims at detecting and fixing the learning deficiencies and needs of students throughout the learning process. Formative assessment uses traditional paper and pencil quizzes, revision tests, exercises, question-answer sessions etc. However, as the learning approaches have become digitalized (e.g. e-learning, mobile learning, flipped learning, ubiquitous learning etc.), it has become inevitable for the measurement and assessment instruments to become digitalized, too. The extensive availability of internet has introduced innovative assessment systems like electronic exams (e-exam), web-based exam or online tests (Başol, Kocadağ Ünver, \& Çiğdem, 2017), which are commonly referred as classroom response systems. With this transformation, such Web 2.0 tools as Socrative, Kahoot!, Plickers, Google Forms, Quizizz etc. have become widely used in education.

Considering the formative assessment value of electronic exams, it can be said that thanks to regular and instant feedback facility learners' progress can be monitored sustainably and their mistakes and misconceptions can be detected and fixed duly. Due to the funny and competitive nature of these platforms, they are also commonly referred to as gamification tools (Ucar \& Kumtepe, 2017). In higher education using gamification has increased considerably over the last decades (Varannai, Sasvári, \& Urbanovics, 2017). One of the most popular game-based learning platform used in education is Kahoot! (Ismail \& Mohammad, 2017). Kahoot! is also preferred as a common formative gamification tool for formative assessment purposes (Alsancak Sırakaya, 2017; Taşkın \& Kılıç Çakmak, 2017). However, there is limited research conducted both in Turkey and abroad about gamification particularly through popular digital response systems in education (Özkan \& Samur, 2017; Varannai, Sasvári, \& Urbanovics, 2017). Thus in this study, it was intended to report researchers' experiences and evaluations about using Kahoot! as a gamified formative assessment tool in a limited context of prospective teacher education program.

\section{Literature Review}

\section{Formative and Summative Assessment}

Traditionally there are two approaches in educational assessment: formative and summative. Formative assessment is an integral part of teaching, intends to promote learning, and takes into account the progress of each individual, while summative assessment involves quality assurance procedures and takes place at certain intervals when achievement has to be reported (Harlen \& James, 1997). Formative assessment collects data during instruction to monitor how well learner progress, however summative assessment collects data after instruction to make judgments about "grading, certification, evaluation of progress, or research on effectiveness" (Bloom, Hastings, and Madaus, 1971, p. 117).

The process-based approach adopted by the classical formative assessment is comparable to the contemporary alternative or complementary assessment approaches. This is because formative assessment aims at detecting and fixing the learning deficiencies and needs of students throughout the learning process. As the main focus is learners pace of development, rather than the product, grading is not a priority as in summative assessment. Through formative assessment, teachers not only monitor how learners progress, but also they reflect on the excellence of instruction they provide finding ways to improve it. A variety of traditional measurement tools and methods are used for formative assessment purposes including paper and pencil quizzes, revision tests, exercises, question-answer sessions etc. 
However, as the learning approaches have recently become more and more technology-based and digitalized (e.g. e-learning, mobile learning, flipped learning, ubiquitous learning etc.), it has become inevitable for the measurement and assessment instruments to become digitalized, too.

\section{The rise of digital assessment tools}

Enhancing learner interaction, motivation and active participation has been facilitated by internet assisted instructional applications, which provide the teachers with the opportunity to make instant assessment and get instant feedback about learners' performance. The extensive availability of internet has introduced innovative assessment systems like electronic exams (e-exam), web-based exam or online tests (Başol et al., 2017). These systems are commonly referred as classroom response systems. Classroom response systems use "wireless handheld devices like smart phones and tablets to collect and aggregate student responses instantly then display the aggregated results in the class and gather immediate feedback in response to questions posed by instructors" (Chaiyo \& Nokham, 2017, p. 178). With this transformation, such Web 2.0 tools as Socrative, Kahoot!, Plickers, Google Forms, Quizizz etc. have become widely used in education.

These digital assessment tools allow students to respond promptly to questions via computers, smart phones or tablets, providing teachers with the opportunity to offer instant feedback for individual or group evaluation in a cheerful and competitive way (Yılmaz, 2017). Moreover, a large spectrum of item formats including true-false, multiple-choice, matching, ordering, cloze-test etc. can be developed and administered easily through online portals (Başol et al., 2017). While multiple-choice tests, for example, have been around for a long time, apps like Plickers, Google forms and Kahoot have made them more interactive and engaging in the classroom (Howell, Tseng, \& Colorado-Resa, 2017).

Considering the formative assessment value of electronic exams, it can be said that thanks to regular and instant feedback facility learners' progress can be monitored sustainably and their mistakes and misconceptions can be detected and fixed duly, slow learners or underachievers can be supported better by the teachers (Başol et al., 2017). Moreover the instant feedback can allow instructors to tailor their instruction in line with students' understanding and surveys can allow learners to participate various decision making procedures anonymously (Plump \& LaRosa, 2017).

Furthermore, such digital applications can be said to match with the needs and interest of the young learners, commonly called as digital natives (Başol et al., 2017). As a matter of fact, Digital natives can no longer be motivated with traditional instructional tools (Premarathne, 2017), and this new generation grows more familiar with the technology (Özdemir, 2017). This generation has been born to a digitalized world thus smart tools are inevitable parts of their daily life (Varannai, Sasvári, \& Urbanovics, 2017).

\section{Digital assessment tools and gamification}

Digital games engage and motivate learners in meaningful and fun activities during the learning process (Dellos, 2015). Due to the funny and competitive nature of these platforms, they are also commonly referred to as gamification tools (Ucar \& Kumtepe, 2017). laremenko (2017, p. 128) defines gamification "as the application of game elements into education which makes it more relaxed, fun and comfortable for students." In higher education using gamification has increased considerably over the last decades (Varannai, Sasvári, \& Urbanovics, 2017). Main reason for the popularity of gamification in education can be attributed to its positive effects on motivation, on higher order cognitive skills including, e.g. problem solving and critical thinking, or on social skills like cooperative work skills (Özkan \& Samur, 2017). Another reason for the popularity of gamification is because it is "one of the most effective strategies to break with routine and boredom and to encourage active learning." (laremenko, 2017, p. 131). It can be stated that gamification motivates people to learn more using these applications, however the bulk of research 
on gamification and its impact on learning is very limited both in Turkey and abroad (Özkan \& Samur, 2017; Varannai, Sasvári, \& Urbanovics, 2017)

One of the most popular game-based learning platform used in education is Kahoot! (Ismail \& Mohammad, 2017). Kahoot! is also preferred as a common formative gamification tool for formative assessment purposes (Alsancak Sırakaya, 2017; Taşkın \& Kılıç Çakmak, 2017). In their studies with prospective preschool teachers Bicen \& Kocakoyun (2017) found participants preferred Kahoot! the most (39\%) from among the educational gamification tools like ClassDojo, Classcraft and Socrative. It can transform multiple-choice questions into exciting, interactive, game-based activities (Howell, Tseng, \& Colorado-Resa, 2017).

\section{Kahoot!}

The idea for Kahoot! originally belongs to a Norwegian Computer Science and Game Technology professor Alf Inge Wang, and the technology is based on the master's degree research of Morten Versvik, who is the co-founder of Kahoot! and Wang's student for (Kahoot, 2018). Kahoot! is a free, online gamification tool and learning platform, where educators can develop and share interactive quizzes, surveys, discussion topics and jumble games in the classroom with unlimited number of participants (Atilano, 2017).

Kahoot! is a dynamic platform, gradually improving itself. One can open a Kahoot! account on https://create.kahoot.it web page for free. Using 'create' option, now you can develop four types of Kahoot games: quiz, discussion, jumble and survey. It allows the users to add pictures or YouTube videos to Kahoot! projects. It is also possible to make the project available for everyone or keep it for yourself only. You can dublicate and edit hundreds of ready Kahoot projects using the discover option. While preparing a Kahoot quiz you can set optional time limits $(5,10,20,30,60,90,120$, seconds) for students to answer the question or award more points to students who answer question correctly faster than other to make the game more competitive. Before starting to play a quiz in the classroom, teacher uses her free account on https://create.kahoot.it and click on 'play' option to start the game in either classic (player vs. player) or team (team vs. team) mode. The screen must be projected on a large screen. Next the students must connect to kahoot.it on their mobile devices to insert the unique pin code provided on the screen. Students are given four options at most, represented by four symbols: a triangle, a diamond, a circle and a square. All students are required to thick on the relevant symbol no later than the pre-set time limit ends. Following screen shows the distribution of answers across the options with a tick or ticks on the correct one(s).

Following is a list of combination of advantages attributed to Kahoot (Ismail \& Mohammad, 2017, p.24; Plump \& LaRosa, 2017, p.157): 1. Freely available for anyone to use, 2. Easy for instructors to learn and user-friendly, 3. Multiple types of Kahoot, i.e. Quizzes, discussion questions, or surveys, 4. Compatible with smartphones, tablets, or ordinary computers; 5 . The response time for each question is flexible and adjustable according to students' needs, 6. Simple process for students (no account registration or downloading of application), 7. Music and colours add to students' excitement and energy, 8. Real-time results help instructors provide clarification when needed, 9. Instructors can download, review, and save student results, 10 . Students can take quizzes multiple times

This free online learning platform has been popularized very fast around the world with more than 30 million users (Plump \& LaRosa, 2017, p. 151). However, there is limited research about the strengths or limitations of this or similar popular digital response systems in education as compared to the traditional paper-pencil assessment tools or methods. 
A comprehensive review of previous researches has revealed positive results about the impact of digital assessment tools in general and Kahoot! in particular, either based on students views or experimental studies (Alsancak Sırakaya, 2017; Atilano, 2017; Barnes, 2017; Budiati, 2017; Başol, Kocadağ Ünver, \& Çiğdem, 2017; Bolat, Şimşek, \& Ülker, 2017; Chaiyo \& Nokham, 2017; laremenko, 2017; Ismail \& Mohammad, 2017; Küçük, 2017; Medina \& Hurtado, 2017; Omar, 2017; Plump \& LaRosa, 2017; Premarathne, 2017; Zengin, Bars, \& Şimşek, 2017; Yılmaz, 2017; Yapıcı and Karakoyun, 2017; Walsh, 2017; Varannai, Sasvári, \& Urbanovics, 2017; Ucar \& Kumtepe, 2017; Taşkın \& Kılıç Çakmak, 2017; ). An overview of the reasons for this positive impact indicated that interactivity created by Kahoot makes quizzes more engaging, interesting, motivating (Omar, 2017). It creates a fun and competitive environment which promotes learning (Deloos, 2015). The competitive atmosphere created by Kahoot! enhances the learner engagement (Barnes, 2017). It serves best to the purposes of formative assessment during the lesson (Barnes, 2017; Zengin, Bars, \& Şimşek, 2017). It is user friendly and benefits both educators and students (Deloos, 2015).

However, some research findings also reported criticisms against Kahoot. For example, Omar (2017) evaluated the effectiveness of Kahoot! activities in terms of feedback quality. As a result she found that performance ranking is not based on clear guidelines, which actually do not necessarily relate to critical thinking skills; it does not deliver high-quality information to students about their learning; and it does not encourage teacher and peer dialogue around learning, as answers are shown for a few seconds not sparing enough time to discuss the answers.

\section{Purpose of the study}

The main purpose of this case study is to describe and evaluate the researchers' experiences about using Kahoot! as a gamified formative assessment tool in a bounded context of prospective teacher education.

\section{METHOD}

\section{Design}

In this case study, the Kahoot! software has been used as a gamified formative assessment tool during the measurement and evaluation courses carried out within the scope of pedagogical formation education for five weeks. According to Yin (2014) "the case study can be on any topic, but it must have some empirical method and present some empirical (qualitative or quantitative) data" (p. 17). The context and participants of the investigated case are explained below.

\section{Research Context \& Participants}

The study took place in four classes of pedagogical formation program held at Inonu University, Malatya, Turkey. Offering 25-credit theoretical and practical courses in two semesters to award the participants with a teaching pedagogy certificate, this program accepts students from different faculties including Turkish Language and Literature, History, Philosophy, Sociology, Business, Sports, Nursing, Music, Art etc. In this research, students in four classes were administered formative exams including multiple-choice items via Kahoot! about the content covered in the previous courses by the first author. Based on students' answers, the instructor (first author) identified the students' learning deficiencies and provided them with explanatory or corrective feedback. At the end of the sixth week all participants were given an online questionnaire form including both close- and open-ended questions (see Data collection below), to which only 88 students responded. 


\section{Data Collection}

Data was gathered through an online questionnaire entitled «Evaluation form for Kahoot!». Of the 164 students, 88 responded the questionnaire. There were close- and open-ended items in the questionnaire such as demographic information about the participants (gender, department etc.) and questions about students' experiences and views about Kahoot (Have you ever used Kahoot! or a similar digital tool in any of your classes before?, How fun do you think Kahoot is?, How teaching do you think Kahoot is? Do you recommend Kahoot to teachers?). In addition, the following two open-ended questions were asked in order to collect richer data on students' opinions about the practice: Based on your classroom experience please write about your; 1. Positive opinions about the Kahoot? What are the strengths of Kahoot? 2. Negative opinions about the Kahoot? What are the weakness of Kahoot?

Though this was not an experimental study with a treatment vs. control group, all students' scores of the mid-term exams were used in order to compare the achievements of the two different student groups: students with whom Kahoot was used (classes from 18th to 21st) and students with whom Kahoot was not used (classes from 1st to 17th). For this purpose, the mid-term exam grades of students were compared with the grades of the other students studying at the other 18 classes.

\section{Data Analysis}

Students' responses on the closed-ended questions were analyzed with SPSS using descriptive statistics (frequency and percent). To compare the mid-term exam grades of the students according to the Kahoot usage independent samples t test was administered. Students' responses on the open-ended questions was analyzed with the NVivo 10 software. During each stage of the qualitative data analysis process, peer debriefing and consistency analysis was carried out.

\section{FINDINGS}

Before students were asked to write their views about the practice of Kahoot, they were asked to response a short questionnaire about their previous experience with Kahoot or similar digital tools, how fun and how teaching they find it, and whether they would recommend it to other teachers. The results are presented below in table 1.

Table 1.

Students' responses to survey

\begin{tabular}{|c|c|c|c|}
\hline Statements & Response & $f$ & $\%$ \\
\hline Have you ever used Kahoot! or a similar digital & Yes & 17 & 19,32 \\
\hline \multirow[t]{2}{*}{ tool in any of your classes before? } & No & 71 & 80,68 \\
\hline & Total & 88 & 100 \\
\hline \multirow[t]{6}{*}{ How fun do you think Kahoot is? } & Not fun at all & 0 & $0,0 \%$ \\
\hline & Not fun & 3 & $3,4 \%$ \\
\hline & Somewhat fun & 5 & $5,7 \%$ \\
\hline & Fun & 12 & $13,6 \%$ \\
\hline & Quite fun & 68 & $77,3 \%$ \\
\hline & Total & 88 & 100 \\
\hline \multirow[t]{3}{*}{ How teaching do you think Kahoot is? } & Not teaching at all & 0 & $0,0 \%$ \\
\hline & Not teaching & 0 & $0,0 \%$ \\
\hline & Somewhat teaching & 5 & $5,7 \%$ \\
\hline
\end{tabular}




\begin{tabular}{|c|c|c|c|}
\hline Statements & Response & $f$ & $\%$ \\
\hline & Teaching & 11 & $12,5 \%$ \\
\hline & Quite teaching & 72 & $81,8 \%$ \\
\hline & Total & 88 & 100 \\
\hline \multirow[t]{6}{*}{ Do you recommend Kahoot to teachers? } & Not Recommend to any teachers & 0 & $0,0 \%$ \\
\hline & Not recommend to most teachers & 1 & $1,1 \%$ \\
\hline & Recommend to some teachers & 2 & $2,3 \%$ \\
\hline & Recommend to most teachers & 13 & $14,8 \%$ \\
\hline & Recommend to all teachers & 72 & $81,8 \%$ \\
\hline & Total & 88 & 100 \\
\hline
\end{tabular}

As it is seen in table 1 , most students $(f=71 ; 80,68 \%)$ had experienced Kahoot! or a similar classroom response system in their classes for the first time. When asked about the entertainment nature of it, $77,3 \%(f=68)$ of the students stated Kahoot! was quite fun and $13,6 \%(f=12)$ said it was fun, while none of the students found It not fun at all. When asked about pedagogical value of Kahoot, 81,8\% ( $f=72$ ) stated it was quite teaching and $12,5 \%$ ( $f=11)$ said it was teaching, while none of the students said it was not teaching or not teaching at all. Finally, when asked for their intention to recommend it to other teachers $81,8 \%(f=72)$ stated they would recommend it to all teachers and $14,8 \%(f=13)$ said they would recommend it to most teachers, while no students said they would not recommend it to any teachers.

Next the students were asked two open-ended questions to reflect about their views about the positive (strengths) and negative (limitations) aspects of using Kahoot! based on their experiences during classes. All students reflected on these two questions, responses ranging from one word to a lengthy paragraph. Results of the content analysis revealed some major themes under two categories (i.e. strengths and limitations) as shown in table 2 below:

Table 2.

Students' views about the strengths and limitations of Kahoot!

\begin{tabular}{|c|c|c|}
\hline Strengths & $f$ & Sample statements \\
\hline Learning retention & 61 & $\begin{array}{l}\text { "Using Kahoot, we review the subject taught in the previous lesson. The } \\
\text { lecturer detects the unlearned points through questions in Kahoot. He makes a } \\
\text { revision on those points. Thus, we revise what we have learned ensuring better } \\
\text { retention. It is more useful." (Yasemin, candidate Turkish Language and } \\
\text { Literature teacher, scored } 57 \text { in mid-term exam) } \\
\text { "A perfect tool helping us keep our knowledge refreshed and not to forget." } \\
\text { (Bilge, candidate History teacher, scored } 40 \text { in mid-term exam) }\end{array}$ \\
\hline Formative assessment & 38 & $\begin{array}{l}\text { "It is an effective tool, which enables the lecturer to see our wrong and correct } \\
\text { answers instantly, to see our competences and incompetence about the } \\
\text { subject, and to make a general revision," (Cemile, candidate Turkish Language } \\
\text { and Literature teacher, scored } 53 \text { in mid-term exam) } \\
\text { "Just like in an exam, we realize what we don't know, and decide on what to } \\
\text { study more" (Rabia, candidate Accounting and Finance teacher, scored } 80 \text { in } \\
\text { mid-term exam). }\end{array}$ \\
\hline Entertainment & 21 & $\begin{array}{l}\text { "It makes the lesson entertaining" (Buket, candidate Justice teacher, scored } 63 \\
\text { in mid-term exam) }\end{array}$ \\
\hline
\end{tabular}




\begin{tabular}{|c|c|c|}
\hline Strengths & $f$ & Sample statements \\
\hline Competitiveness (motivating) & 11 & $\begin{array}{l}\text { "Moreover, the kind but firm competition is quite significant and effective." } \\
\text { (Ömer, candidate Turkish Language and Literature teacher, scored } 70 \text { in mid- } \\
\text { term exam) } \\
\text { "It motives students to study before coming to class, leading them to some kind } \\
\text { of competition, that is it encourages students for success (Hatice, candidate } \\
\text { Chemistry teacher, scored, } 83 \text { in mid-term exam) }\end{array}$ \\
\hline Engagement & 10 & $\begin{array}{l}\text { "Kahoot engages the students to lesson" (Şerif, candidate History teacher, } \\
\text { scored } 43 \text { in mid-term exam) }\end{array}$ \\
\hline Motivation & 9 & $\begin{array}{l}\text { "Kahoot! motivates even the clock-watchers, who are used to do nothing but } \\
\text { just come and sit during the lesson without any preparation" (Yunus, candidate } \\
\text { History teacher, scored } 63 \text { in mid-term exam) }\end{array}$ \\
\hline Instant response & 7 & $\begin{array}{l}\text { "The strongest and the most positive aspect of Kahoot practice is instant } \\
\text { disclosure of correct answers." (Enes, candidate Music teacher, scored } 27 \text { in } \\
\text { mid-term exam) }\end{array}$ \\
\hline Usefulness & 3 & $\begin{array}{l}\text { "It is practical." (Akif, candidate Turkish Language and Literature teacher, } \\
\text { scored } 53 \text { in mid-term exam) }\end{array}$ \\
\hline \multicolumn{3}{|l|}{ Limitations } \\
\hline Short span of time & 28 & $\begin{array}{l}\text { "Since there is limited time to answer, we can not find enough time to think on } \\
\text { the answer." (Gülsen_candidate Nursing teacher, scored } 57 \text { in mid-term exam) } \\
\text { "Since the response time is very short, the rush to answer the question in time } \\
\text { causes mistaken markings on the phone screen. This is a kind of random error, } \\
\text { which does not indicate that student does not actually know the correct } \\
\text { answer." (Sabiha_candidate Accounting and Finance teacher, scored } 67 \text { in mid- } \\
\text { term exam) }\end{array}$ \\
\hline Competitiveness (demotivating) & 8 & $\begin{array}{l}\text { "I believe the only negative aspect is that it provokes competition" (Ayşe_ } \\
\text { candidate Turkish Language and Literature teacher, scored } 63 \text { in mid-term } \\
\text { exam) }\end{array}$ \\
\hline Limited internet access & 6 & $\begin{array}{l}\text { "Not everyone could play it, I mean those without mobile internet." (Esra, } \\
\text { candidate History, scored } 42 \text { in mid-term exam) }\end{array}$ \\
\hline Inadequate number of questions & 4 & $\begin{array}{l}\text { "More questions could have been asked covering a more comprehensive } \\
\text { content." (Cemile, candidate Turkish Language and Literature teacher, scored } \\
53 \text { in mid-term exam) }\end{array}$ \\
\hline Small screen & 1 & $\begin{array}{l}\text { "Students at the back raws may not see the screen and read the questions } \\
\text { well." (Eda, candidate Turkish Language and Literature teacher, scored } 60 \text { in } \\
\text { mid-term exam) }\end{array}$ \\
\hline Difficulty of questions & 1 & $\begin{array}{l}\text { "The questions were difficult." (Büşra, candidate Turkish Language and } \\
\text { Literature teacher, scored } 53 \text { in mid-term exam) }\end{array}$ \\
\hline Noise during the activity & 1 & "Since not everybody keeps silent, I could not use the response time well" \\
\hline
\end{tabular}




\begin{tabular}{ll}
\hline Strengths & Sample statements \\
\hline & (Rabia, candidate Accounting and Finance teacher, scored 80 in mid-term \\
& exam). \\
\hline
\end{tabular}

The analysis of the students' answers to open ended questions revealed that the most recited strength of Kahoot! was ensuring learning retention. Accordingly, using Kahoot! provided the students with opportunities to repeat, review and revise the previous subjects during the testing session and following revision by the lecturer. This ensures learning retention as the students regularly refresh and revise their prior knowledge. Secondly, students emphasized and praised the formative assessment function of Kahoot!, through which lecturer monitors students' progress and learning outcomes in order to improve the process. Thirdly, students frequently had mention of how entertaining and fun the practice of Kahoot! was. Next theme was rather controversial one since the nature of competitiveness was perceived and experienced in opposite directions. From the positive perspective, some students believed that gamification nature of Kahoot! created a rather constructively competitive atmosphere. This competitive atmosphere motivated them and others to study more in order to be successful. Either because of the entertaining or competitive nature, students also emphasized that students' motivation to study and active engagement to lessons increased thanks to Kahoot! practices. As related with formative assessment, the instant response function of Kahoot! was also mentioned as a splendid feature supporting the learning process of the students. Last but not the least, some students had mention of how useful and handy Kahoot! is as an assessment tool, since there is no need for traditional paper-pencil quizzes and time-consuming grading and feedback procedures.

Students' responses also included some criticisms about the limitations of formative assessment with Kahoot!, though less in number than strengths. When examined closer, it can be understood that most of the criticisms do not stem from Kahoot! itself, but from the way it was used by the instructor. For example, students mostly complained about the short span of time limit set for students to answer the questions since this supposedly caused an unnecessary hurry, possible carelessness and eventually some random errors. Since the countdown options for each question includes 5, 10, 20, 30, 60, 90, or 120 seconds, it is up to the lecturer to gauge it according to some contextual factors like difficulty of the question, age of the students, purpose of the activity (e.g. competition or giving feedback etc.). Secondly, some students perceived and experienced the nature of competitiveness in Kahoot! activities in a negative direction. Accordingly, some students complained about Kahoot!, since it created a rather destructively competitive atmosphere, which demotivated them. Another important limitation, both participants mentioned and the researchers observed during their lessons, was limited access to internet. Some students may fail to participate the Kahoot! activities simply because they do not have a mobile device or internet connection on their mobile. Several students complained about the inadequacy of the number of questions, which is concerned with the researcher rather than Kahoot! itself. The tests used during five weeks included 10 to 15 questions. Though there is no limit for the number of questions, the lecturer need to decide about the number of questions considering some contextual factors including lesson time, lesson content, content of the previous lessons etc. Last but not the least, some other important points, which should be taken into consideration while using Kahoot for formative purposes were quality of students' vision (screen should be large enough or students should be located so that everybody could read the questions easily), whether the difficulty of the questions are suitable for formative assessment purposes and noise during the Kahoot! activities, which should be removed through negotiated rules and polite instructions.

Though this was not an experimental study with a treatment vs. control group, it was decided to compare the midterm scores of students in classes 18th to 21st, where Kahoot! was used as a gamified formative 
assessment tool, and others in classes 1st to 17th. Results of independent samples t test are presented in table 3.

Table 3.

Comparison of midterm scores of students in classes where Kahoot! was used with the scores of others

\begin{tabular}{|c|c|c|c|c|c|c|c|c|}
\hline Classes & $\mathrm{N}$ & Mean & $S$ & $\mathrm{~S}_{\mathrm{e}}$ & df & $\mathrm{t}$ & $\mathrm{p}$ & Cohen's d \\
\hline Classes experiencing Kahoot! $^{\mathrm{a}}$ & 153 & 53,68 & 14,84 & 1,20 & \multirow{2}{*}{894} & \multirow{2}{*}{6,559} & \multirow{2}{*}{.000} & \multirow{2}{*}{$\begin{array}{l}.582 \\
\text { (Moderate) }\end{array}$} \\
\hline Other classes ${ }^{b}$ & 743 & 45,21 & 14,49 & 0,53 & & & & \\
\hline
\end{tabular}

$* \mathrm{p}<.05$;

${ }^{a}$ Classes where Kahoot! was used as a formative assessment tool for five weeks ( $18^{\text {th }}$ to 21 st).

${ }^{b}$ Other classes $\left(1^{\text {st }}\right.$ to $\left.17^{\text {th }}\right)$ no similar practice was reported.

As it is seen in table 3 , the mean midterm scores (mean=53,68) of classes experiencing Kahoot! (153 out of 164 registered students in 18th-21st classes got a valid score) was statistically significantly higher than that of 743 students in other classes (mean=45,21), $\mathrm{t}(894)=6,559, \mathrm{p}<.5$. Considering the moderate level of the estimated effect size (Cohen's $d=582$ ), this difference is also significant in practical terms. Since all students in 21 classes were taught the same content and administered the same question in the midterm exam, this may be interpreted as a statistical evidence for the positive effect of gamified formative assessment activities via Kahoot! on learning. However, this difference cannot be necessarily attributed to Kahoot! activities as the compared groups were not either randomized or matched, nor were they taught by same instructors.

\section{DISCUSSION}

This rather limited case study intended to report researchers' experiences and evaluations about using Kahoot! as a gamified formative assessment tool in a bounded context of prospective teacher education program. Initial quantitative findings suggested that most of the participants have not experienced an inclass assessment practice via a digital response system before, it was quite entertaining and teaching for them, and it deserves to be recommended to all other teachers. Thus it can be concluded that participants were highly positive about using Kahoot! as a gamified formative assessment tool from attitudinal and pedagogical aspects. These results are highly consistent with the results of previous researches about electronic response systems in general and Kahoot! in particular. For example, Başol, Kocadağ Ünver, \& Çiğdem (2017) reported that out of 127 preservice teachers who received e-exams on MOODLE, 96\% found the e-exams useful, 94\% believed they supported their learning, and 92\% preferred e-exams to be used in other lessons. Premarathne (2017) reported that gamification via Kahoot! as a formative assessment tool resulted in better learner attendance, intrinsic motivation, and concentration. Moreover, among several digital response systems, Kahoot! seems to be the most popular one. Taşkın \& Kılıç Çakmak (2017) found that especially Kahoot!, among other tools (e.g. ClassDojo, Facebook, Surveey, Kahoot!, Padlet, Text2mindmap), increased students' cognitive, affective and behavioral engagement levels. Students prefer gamification activities via Kahoot! be used in other classes (Alsancak Sirakaya, 2017).

More detailed analysis based on students' answers to open ended questions revealed that Kahoot! was most appreciated for ensuring learning retention and its formative assessment function. Both of these major strengths prove that formative assessment via Kahoot! supports students' learning. Moreover, the relative superiority of the mid-term exam scores of students who were subjected to gamified formative 
assessment for five weeks over the mid-term exam scores of other students can be attributed - to some extent - to the positive impact of formative assessment via Kahoot! on students' learning. Previous research findings also highlight this positive impact on academic achievement either based on students' self-reports or through experimental studies. For example, Plump \& LaRosa (2017) found that 86,5\% of the 139 university students thought Kahoot! helped them with their contceptual understanding. Similarly, Başol et al. (2017) reported that $74 \%$ of the participating 127 students thought e-exams helped them detect and make up their learning deficiencies. Medina \& Hurtado (2017) also found 74\% of students believed using Kahoot! helped them prepare for formal exam. In Borrell, Cosmas, Grymes, \& Radunzel (2017), 75\% of respondents admitted they studied more to get prepared for a pre-lesson Kahoot! quiz. Zengin, Bars, \& Şimşek (2017) stressed that Kahoot! and Plickers make remarkable contribution to detection and elemination of unlearned topics through formative assessment. In their experimental research, on the other hand, Bolat, Şimşek, \& Ülker (2017) found that beneficial to easy learning, increase retention, learning speed, Kahoot! helped candidate mathematics teachers to learn computer subjects better. In a single subject design, Pede (2017) found Kahoot improved the science vocabulary test scores of all six disabled students.

From attitudinal aspects, sense of entertainment was a major impact of formative assessment via Kahoot! This can be attributed to the gamification nature of Kahoot! especially as a result of the competitive atmosphere it creates. However, the nature of competitiveness was perceived and experienced in exactly two opposite directions. From the positive perspective, the competitive atmosphere created by Kahoot! was constructive motivating students to actively participate or study more in order to be successful. In line with the findings of the present study, the adjectives or attributes most commonly associated with Kahoot! included fun/funny or entertaining (Budiati, 2017; Bolat et al., 2017; Chaiyo \& Nokham, 2017; laremenko, 2017; Ismail \& Mohammad, 2017; Yapıcı \& Karakoyun, 2017), joyful/enjoyable (Budiati, 2017; Chaiyo \& Nokham, 2017; Ismail \& Mohammad, 2017; Pede, 2017; Plump \& LaRosa, 2017), interesting (Budiati, 2017; Chaiyo \& Nokham, 2017), motivating or engaging (Atilano, 2017; Bolat et al., 2017; Chaiyo \& Nokham, 2017; Ismail \& Mohammad, 2017; Yapıcı \& Karakoyun, 2017). Also there is good amount of recent research findings about the association between entertainment, competitiveness, motivation and engagement aspects of digital response systems and Kahoot! in particular. For example, laremenko (2017) suggested that funny and competitive atmosphere created via Kahoot! can provide learners with additional intrinsic motivation. Varannai, Sasvári, \& Urbanovics (2017) pointed that gamification through Kahoot! sustainably motivates learners preventing absence in lectures and seminars. Zengin, Bars, \& Şimşek (2017) reported Kahoot! and Plickers increased students interaction and participation. Alsancak Sirakaya (2017) reported that students' engagement increased as a result of competitive nature of Kahoot! based gamification activities. According to Borrell, Cosmas, Grymes, \& Radunzel (2017) the competition provided via Kahoot! is friend in nature. Alsancak Sırakaya, (2017) also argue that gamification activities with Kahoot! help creating an interactive social learning environment .

Integral to formative assessment, instant response capability of Kahoot! was found to be a remarkably useful function supporting the learning process of the students. Plus, Kahoot! was found a much more handy and easy assessment tool compared to traditional paper-pencil quizzes and time-consuming grading and feedback procedures. This finding is also in agreement with the previous research findings. For example, Pede (2017) found even the disabled middle school students found Kahoot easy to use. Plump \& LaRosa (2017) reported 92,9\% of the students found Kahoot easy to use. This rate was $100 \%$ in a study by Medina \& Hurtado (2017). Ismail \& Mohammad (2017) also found that Kahoot is a promising formative assessment tool as it is feasible and practical. Zengin, Bars, \& Şimşek (2017) concluded in their study that Kahoot! and Plickers are practical formative evaluation tools providing detailed and instant analysis in a short time.

Though less in number than strengths, some criticisms about the limitations of formative assessment with Kahoot! was also highlighted by students'. However, it was concluded most of the criticisms was not 
directed to Kahoot! itself, but to the way it was used by the instructor. The major complaint was the short span of time limit set for students to answer the questions since this supposedly caused an unnecessary hurry, possible carelessness and eventually some random errors. Similarly, Bolat, Şimşek, \& Ülker (2017) found that students recommend the duration of the questions should be appropriate. Since the countdown options for each question includes $5,10,20,30,60,90$, or 120 seconds, it is up to the lecturer to gauge it according to some contextual factors like difficulty of the question, age of the students, purpose of the activity (e.g. competition or giving feedback etc.).

Unlike the its motivating value, competitive nature of Kahoot! activities was also found to be destructive as the winner and loser categorization demotivated the students. Similarly, Bolat et al. (2017) found that some students stated that the competitive environment had negative effects on the learning. YapıcI \& Karakoyun (2017) also emphasized that ranking the students according to their score can be demotivating for the students at the bottom of the list and inadequate technology literacy on the part of preservice teachers poses a limitation. Actually, competition is an inevitable part of gamification. However, competitive reward systems may degrade learners' motivation in the long run and can cause undesired outcomes especially with young learners (Özkan \& Samur, 2017).

Another important limitation was lack of mobile devices or internet. Students' failure to participate the Kahoot! activities simply because they do not have a mobile device or internet connection was also a cause of students' demotivation. The relevant literature also points out that the most important limitation about electronic exams in general and Kahoot in particular is a failure to provide students with adequate ICT support and internet connection (Başol et al., 2017; Bolat et al., 2017; Budiati, 2017; Yılmaz, 2017; Zengin et al., 2017). To give a striking example, Yılmaz (2017) admits she had to quit using Kahoot! owing to shortage of internet connection and shifted to Plickers with 6th graders. From a different perspective, Yapıcı \& Karakoyun (2017) also emphasized inadequate technology literacy on the part of preservice teachers posed them a problem. Technology adequecy in terms of both infrastracture and literacy should be considered seriously in order not to exclude some students from a collective activity just because they cannot afford or use mobile internet connection.

Several other complains by the participating students included the inadequacy of the number of questions, quality of students' vision (screen should be large enough or students should be located so that everybody could read the questions easily), maladjustment of the difficulty of the questions and noise during the Kahoot! activities. Similar complaints recited in previous researches included the limited number of characters one can use in questions and responses, and inapplicability of asking open-ended questions or receiving open-ended responses for now (Plump \& LaRosa, 2017, p. 157). With regard to the quality and quantity of questions and presentation, the lecturer need to decide about the number and difficulty of questions considering some contextual factors including lesson time, lesson content, content of the previous lessons etc. Also for the presentation of the Kahoot activities, it should be ensure that all students can see the screen and rules to follow during the activity should be negotiated with polite instructions before the activity starts.

\section{Conclusion and Implications}

This small-scale case study demonstrated us that Kahoot and similar digital response systems are quite promising in providing an effective formative assessment platform producing favorable practical, pedagogical, and affective outcomes. When supported with principles of gamification, the sense of competition it creases motivates and engages learners into lesson. The repetitions through formative assessment activities support students' learning and ensure learning retention. While such digital response systems are gradually finding their ways into classrooms at all stages of education, main 
challenge seems to be a failure on the part of instructors to possess the "opportunity, experience, or understanding to utilize digital games within their classrooms." (Plump \& LaRosa, 2017, p. 152). However, As teacher trainers, we should actively model in our lessons the most up-to-date educational technologies. Thus, the student teachers can be convinced about the importance and usefulness, if so, of these technologies. As a result they can directly observe and experience how these practical technologies can be used.

Considering the negative aspects of Kahoot or similar classroom response systems, it should be acknowledged that most limitations about such technologies do not stem from the application but they are caused by the practitioners' ability to use them in pedagogical ways. As put by Özkan \& Samur, (2017, p. 882) "when effective instructional design is not created, no game elements will be able to help learning or motivation for long-term."

\section{References}

Alsancak Sırakaya, D. (2017). Oyunlaştırılmış tersyüz sınıf modeline yönelik öğrenci görüşleri. Ondokuz Mayis University Journal of Faculty of Education, 36(1), 114-136.

Atilano, M. (2017, 07 27). Game on: Teaching research methods to college students using Kahoot! Library Faculty Presentations \& Publications: Retrieved from http://digitalcommons.unf.edu/library_facpub/56.

Barnes, R. (2017). Kahoot! in the classroom: Student engagement technique. Nurse Educator, 42(6), 280.

Başol, G., \& Johanson, G. (2009). The effectiveness of frequent testing over achievement: A meta-analysis study. International Journal of Human Sciences, 6(2), 99-121.

Başol, G., Kocadağ Ünver, T., \& Çiğdem, H. (2017). Ölçme değerlendirme dersinde e-sınav uygulanmasına ilişkin öğrenci görüşleri. Uluslararası Türk Eğitim Bilimleri Dergisi, 5(8), 111-128.

Bicen, H., \& Kocakoyun, S. (2017). Determination of university students' most preferred mobile application for gamification. World Journal on Educational Technology, 9(1), 18-23.

Bloom, B. S., Hastings, J. T., \& Madaus, G. F. (1971). Handbook on formative and summative evaluation of student learning. New York: McGaw-Hill

Bolat, Y. İ., Şimşek, Ö., \& Ülker, Ü. (2017). The impact of gamified online classroom response system on academic achievement and views about this system. Abant Izzet Baysal Üniversitesi Eğitim Fakültesi Dergisi, 17 (4), 1741-1761.

Borrell, J., Cosmas, N., Grymes, J., \& Radunzel, J. (2017). The effectiveness of Kahoot! as a pre-lesson assessment tool. West Point, NY: Center for Faculty Excellence, United StatesMilitary Academy.

Budiati, B. (2017). Ict (information and communication technology) use: Kahoot program for English students' learning booster. The 1st Education and Language International Conference (s. 178188). Semarang, Indonesia: Center for International Language Development of Unissula.

Chaiyo, Y., \& Nokham, R. (2017). The effect of Kahoot, Quizizz and Google forms on the Student's perception in the classrooms response system. International Conference Digital Arts, Media and Technology, (s. 178-181). Chiang Mai, Thailand.

Dellos, R. (2015). Kahoot! A digital game resource for learning. International Journal of Instructional Technology and Distance Education, 12(4), 49-52. 
Freeman, C. L. (2015, November). Technologies for formative assessment: can web-based applications transform the allied health science classroom and improve summative assessment outcomes. Appalachian State University, USA.

Harlen, W. \& James, J. (1997) Assessment and Learning: differences and relationships between formative and summative assessment. Assessment in Education: Principles, Policy \& Practice, 4(3), 365-379,

Howell, D. D., Tseng, D. C., \& Colorado-Resa, J. T. (2017). Fast assessments with digital tools using multiple-choice questions. College Teaching, 65(3), 145-147.

laremenko, N. V. (2017). Enhancing English language learners' motivation through online games. Information Technologies and Learning Tools, 59(3), 126-133.

Ismail, M.-A., \& Mohammad, J.-M. (2017). Kahoot: a promising tool for formative assessment in medical education. Education in Medicine Journal, 9(2), 19-26.

Kahoot. (2018, 05 01). Who and what is behind Kahoot! https://kahoot.com: https://kahoot.uservoice.com/knowledgebase/articles/464890-who-and-what-is-behind-kahoot adresinden alınmıştır

Küçük, S. (2017). Situated Learning Based Educational Technology Instruction: Preservice Teachers' Experiences. Journal of Higher Education and Science, 7(2), 369-377.

Medina, E. G., \& Hurtado, C. P. (2017). Kahoot! A digital tool for learning vocabulary in a language classroom. Revista Publicando, 12(1), 441-449.

Omar, N. N. (2017). The effectiveness of Kahoot application towards students' good feedback practice. International Journal of Social Sciences, 3(2), 2551-2562.

Özdemir, O. (2017). Usage of digital technologies in Turkish teaching and an example of web implementation. Turkish Studies, 12(4), 427-444.

Özkan, Z., \& Samur, Y. (2017). Oyunlaştırma yönteminin öğrencilerin motivasyonları üzerine etkisi. Ege Eğitim Dergisi, 18(2), 857-886.

Pede, J. (2017). The effects of the online game Kahoot on science vocabulary acquisition. Unpublished MA Special Education Thesis, Rowan University.

Plump, C. M., \& LaRosa, J. (2017). Using Kahoot! in the Classroom to Create Engagement and Active Learning: A Game-Based Technology Solution for eLearning Novices. Management Teaching Review, 2(2), 151-158.

Premarathne, P. B. (2017). A study on incorporating gamification into ESL classroom via Kahoot! International Conference on the Humanities (ICH) (s. 54). Sri Lanka: Faculty of Humanities, University of Kelaniya.

Taşkın, N., \& Kılıç Çakmak, E. (2017). Öğrenci merkezli öğrenme ortamlarında oyunlaştırmanın alternatif değerlendirme amaçı kullanımı. Bartin University Journal of Faculty of Education, 6(3), 12271248. 
Ucar, H., \& Kumtepe, A. (2017). Using the game-based student response tool Kahoot! in an Online class: Perspectives of online learners. Society for Information Technology \& Teacher Education International Conference (s. 303-307). Austin, Texas, USA: AACE.

Varannai, I., Sasvári, P. L., \& Urbanovics, A. (2017). The use of gamification in higher education: an empirical study. International Journal of Advanced Computer Science and Applications, 8(10), 16.

Walsh, R. (2017, August). Turning the smartphone into an EAP classroom learning device through Kahoot! . In EUROCALL2017.

Yapıcı, I. Ü., \& Karakoyun, F. (2017). Gamification in teaching biology. Turkish Online Journal of Qualitative Inquiry (TOJQI), 8(4), 396-414.

Yılmaz, B. (2017). The impact of digital assessment tools on students' engagement in class: a case of two different secondary schools. Abant Izzet Baysal Üniversitesi Eğitim Fakültesi Dergisi, 17(3), 16061620.

Yin, R. K. (2014). Case study research: Design and methods $\left(5^{\text {th }}\right.$ ed.), Thousand Oaks, California: sage publications

Zengin, Y., Bars, M., \& Şimşek, Ö. (2017). Investigation of Using Kahoot! and Plickers in Formative Evaluation Process in Mathematics Teaching. Ege Eğitim Dergisi, 18(2), 602-626. 